\title{
Hans Georg Trüper, Life Member of the ICSP - an appreciation
}

Prior to the meetings of the Judicial Commission of the International Committee on Systematics of Prokaryotes (ICSP) at the Congress of the Bacteriology and Applied Microbiology Division of the International Union of Microbiological Societies (IUMS) in Istanbul in August 2008, Hans G. Trüper announced his retirement from the 24th class of commissioners. Email exchanges among the other commissioners quickly came to the conclusion that there was only one way of honouring his contribution to systematics and the work of both the Judicial Commission and the ICSB/ICSP and that was to propose to the ICSP plenary session to be held in Istanbul that he be elected a Life Member of the ICSP. This course of action was accepted unanimously at the plenary session of the ICSP held on 3 August 2008 in the Salon Göksu, Taksim Gönen Hotel, Istanbul, and Hans Georg Trüper was duly elected a Life Member of the ICSP.

Hans G. Trüper's contribution to systematics and the work of both the Judicial Commission and the ICSB/ICSP covers many facets. During his $\mathrm{PhD}$ thesis at the University of Göttingen, he was introduced to the anoxygenic phototrophic bacteria by Hans G. Schlegel and the late Norbert Pfennig. Although his thesis was on the biochemistry of Chromatium okenii, he also came into contact with work on the isolation and purification of these organisms, developing a dual interest in both their biochemistry and the significance of systematics in this group of organisms. During his postdoctoral work at the Woods Hole Oceanographic Institute, he dealt not only with the description of novel taxa (Trüper \& Jannasch, 1968), but also with the recognition of the importance of the work of earlier generations of scientists (Trüper, 1968). Here too are to be found the first glimmerings of a willingness to tackle issues relating to the Bacteriological Code (the 1966 version being current at that time) as well as putting his skills in classical languages into practice. Hans G. Trüper and Norbert Pfennig published a series of papers dealing with the nomenclature, taxonomy and types/neotypes of members of the anoxygenic phototrophic bacteria in the period 1969-1971 (Pfennig \& Trüper, 1969, 1970, 1971a, b, c, d; Trüper \& Pfennig, 1969, 1971). These publications laid the foundation for the nomenclature and typification of this group of organisms on the Approved Lists of Bacterial Names. Hans G. Trüper is listed as one of the contributors to the Approved Lists of Bacterial Names (Skerman et al., 1980). He also contributed to the 8th edition of Bergey's Manual of Determinative Bacteriology, as well as to the 1st and 2nd editions of Bergey's Manual of Systematic Bacteriology. During his active scientific career, he also contributed to the description of several novel taxa. He served on the editorial board and contributed articles to the 1st, 2nd and 3rd editions of The Prokaryotes, where various aspects of the biology of prokaryotes, including systematics, played a central role. Hans G. Trüper's formal association with the ICSB (now the ICSP) began with his election to the Judicial Commission at the Twelfth International Congress for Microbiology in 1978 in Munich. He served as Secretary for Subcommittees from 1982 to 1990 and chaired the ICSB from 1990 to $1996 . \mathrm{He}$ served on the 15th (1978-1990), 20th (1996-2005) and 24th (2005-2008) classes of the Judicial Commission, which he also chaired from 1996 to 2005 . He was a founder member of the ICSB/ICSP Subcommittees dealing with the taxonomy of phototrophic bacteria and of the family Halobacteriaceae. In the period from 1990 to 2008, Hans G. Trüper served as a member of the editorial board of the International Journal of Systematic Bacteriology and its successor, the International Journal of Systematic and Evolutionary Microbiology (IJSEM). He was Editor of the IJSEM in 2002. During his time in office as a member of the ICSB/ICSP he also served on two ad hoc committees (Wayne et al., 1987; Stackebrandt et al., 2002).
His keen passion for the classical languages (and languages in general) have led to a number of publications designed to help those less familiar (and gifted) in the art of correct Latin grammar (Trüper, 1996, 1999, 2001, 2004). These papers have also led to a more comprehensive and extensively revised version of Appendix 9 of the Bacteriological Code. His name appears at the end of many publications dealing with new taxonomic names, acknowledging his guidance in the derivation of new Latinized names. In 1999, he received the Bergey Medal for 'long-term excellent merits in bacterial taxonomy'.

Apart from his positions in the ICSB/ICSP, Hans G. Trüper was a founder member of the Vereinigung für Allgemeine und Angewandte Mikrobiologie (VAAM), where he helped to establish and was supportive of one of the first subgroups, Identification and Systematics. During his period of office as representative of the VAAM as well as Vice President and President of the Federation of European Microbiological Societies (FEMS), he showed continued support and understanding for the underlying goals of systematics and a properly, formally regulated system of nomenclature, with its associated facets.

Hans G. Trüper has also been honoured by a number of other academic institutions. He was elected as a corresponding member of the Academy of Sciences in Göttingen in 1987 and elected as member of the Wittheit (Academy of Sciences), Bremen, in 2003. He was made an honorary member of the Spanish Society for Microbiology (Sociedad Española de Microbiología) in 1997 and of the VAAM in 2008. The Hebrew University of Jerusalem made him an Honorary Fellow in 2003. In 2002, he received an Honorary Doctorate (Dr rer. nat. h.c.) from the Faculty of Biology and Chemistry, University of Bremen. 
In retiring from the Judicial Commission, Hans G. Trüper's formal association with the ICSP has ended after a period of 30 years, during which time he has made important contributions to the work of this, one of the longest established IUMS ComCoFs (committees, commissions and federations). It is therefore fitting that his contribution should be recognized by his election as a Life Member of the ICSP. The members of the ICSP were unanimous in accepting the proposal that Hans G. Trüper be added to the list of Life Members, both prolonging that association and recognizing his important contribution to this internationally active committee.

\section{Peter Kämpfer ${ }^{1}$ and Brian J. Tindall ${ }^{2}$}

on behalf of the International Committee on Systematics of Prokaryotes

${ }^{1}$ Institut für Angewandte Mikrobiologie, Justus-Liebig Universität Giessen, Heinrich-Buff-Ring 26-32 (IFZ), D-35392 Giessen, Germany

${ }^{2} \mathrm{DSMZ}$ - Deutsche Sammlung von Mikroorganismen und Zellkulturen $\mathrm{GmbH}$, Inhoffenstrasse 7b, D-38124 Braunschweig, Germany

Correspondence: Peter Kämpfer (peter.kaempfer@umwelt.uni-giessen.de)

Pfennig, N. \& Trüper, H. G. (1969). Proposal to declare Rhodopseudomonas palustris and Chloropseudomonas ethylica as nomina conservanda. Int J Syst Bacteriol 19, 153-154.
Pfennig, N. \& Trüper, H. G. (1970). Conservation of the family names Thiorhodaceae Molisch 1907, 27 and Athiorhodaceae Molisch 1907, 28 and designation of Chromatium Perty 1852, 174 as the type genus of the Thiorhodaceae and of Rhodospirillum Molisch 1907, 24 as the type genus of the Athiorhodaceae. A recommendation to the Judicial Commission. Int J Syst Bacteriol 20, 31-33.

Pfennig, N. \& Trüper, H. G. (1971a). New nomenclatural combinations in the phototrophic sulfur bacteria. Int J Syst Bacteriol 21, 11-14.

Pfennig, N. \& Trüper, H. G. (1971b).

Conservation of the family name Chromatiaceae Bavendamm 1924 with the type genus Chromatium Perty 1852. Request for an Opinion. Int J Syst Bacteriol 21, 15-16.

Pfennig, N. \& Trüper, H. G. (1971c). Higher taxa of the phototrophic bacteria. Int J Syst Bacteriol 21, 17-18.

Pfennig, N. \& Trüper, H. G. (1971d). Type and neotype strains of the species of phototrophic bacteria maintained in pure culture. Int J Syst Bacteriol 21, 19-24.

Skerman, V. B. D., McGowan, V. \& Sneath, P. H. A. (editors) (1980). Approved lists of bacterial names. Int J Syst Bacteriol 30, 225-420.

Stackebrandt, E., Frederiksen, W., Garrity, G. M., Grimont, P. A. D., Kämpfer, P., Maiden, M. C. J., Nesme, X., Rosselló-Mora, R., Swings, J. $\&$ other authors (2002). Report of the ad hoc committee for the re-evaluation of the species definition in bacteriology. Int J Syst Evol Microbiol 52, 1043-1047.

Trüper, H. G. (1968). Ectothiorhodospira mobilis Pelsh, a photosynthetic sulfur bacterium depositing sulfur outside the cells. J Bacteriol 95, 1910-1920.
Trüper, H. G. (1996). Help! Latin! How to avoid the most common mistakes while giving Latin names to newly discovered prokaryotes. Microbiologia 12, 473-475.

Trüper, H. G. (1999). How to name a prokaryote? Etymological considerations, proposals and practical advice in prokaryote nomenclature. FEMS Microbiol Rev 23, 231-249.

Trüper, H. G. (2001). Etymology in nomenclature of procaryotes. In Bergey's Manual of Systematic Bacteriology, 2nd edn, vol. 1, pp. 89-99. Edited by D. R. Boone, R. W. Castenholz \& G. M. Garrity. New York: Springer.

Trüper, H. G. (2004). The use of Neo-Latin in biological nomenclature. Neulateinisches Jahrb J Neo-Latin Lang Lit 6, 318-327.

Trüper, H. G. \& Jannasch, H. W. (1968).

Chromatium buderi nov. spec., eine neue Art der "grossen" Thiorhodaceae. Arch Mikrobiol 61, 363-372 (in German).

Trüper, H. G. \& Pfennig, N. (1969). Proposal to declare Rhodopseudomonas sphaeroides as nomen conservandum. Int J Syst Bacteriol 19, 155-156.

Trüper, H. G. \& Pfennig, N. (1971). Family of phototrophic green sulfur bacteria: Chlorobiaceae Copeland, the correct family name; rejection of Chlorobacterium Lauterborn; and the taxonomic situation of the consortiumforming species. Request for an Opinion. Int $J$ Syst Bacteriol 21, 8-10.

Wayne, L. G., Brenner, D. J., Colwell, R. R., Grimont, P. A. D., Kandler, O., Krichevsky, M. I., Moore, L. H., Moore, W. E. C., Murray, R. G. E. \& other authors (1987). International Committee on Systematic Bacteriology. Report of the ad hoc committee on reconciliation of approaches to bacterial systematics. Int J Syst Bacteriol 37, 463464. 